\title{
Inhibiting Factors Inventorying and Mapping Potential Geographical Indications in Riau Province
}

\author{
Rian Saputra ${ }^{1}$ Pujiyono $^{2}$, Sunny Ummul Firdaus ${ }^{3}$ \\ ${ }^{1.2 .3}$ Universitas Sebelas Maret \\ Surakarta, Indonesia \\ rians7010@gmail.com
}

\begin{abstract}
This study aims to obtain information on the factors that hinder the inventory and mapping of potential Geographical Indications as mandated by Article 70 Paragraph (2) letter e of Law Number 20 of 2016 concerning Trademarks and Geographical Indications. This research is a non-doctrinal legal research that analyzes the operation of law in society. The approach taken focuses on the effectiveness of the rule of law, implementation of the rule of law using deductive logic. The primary data collection technique was carried out by in-depth interviews with the informants. The results of the study indicate the lack of understanding of the community and stakeholders in Riau Province about the concept of GI protection, as well as the absence of regional legal politics that is oriented towards the protection and development of GI potential in order to improve the community and regional economy, causing a lot of GI potentials in the Region which are Regional Superior Products not to be registered. and in the Inventory, other than that other factors are that there has not been an equitable socialization regarding the importance of protecting GI and the benefits of its protection by the Directorate General of Intellectual Property
\end{abstract}

Keywords-Geographical Indications, Legal Protection Concepts, Inventory.

\section{INTRODUCTION}

The Republic of Indonesia is a country that is very rich in natural products and local culture. This can be seen from the various types of plants that are owned by almost every region in Indonesia. Such as, Cilembu Sweet Potatoes, Pondoh Salak, Kintamani Bali Arabica Coffee, and so on. In addition, there are many products that are produced based on local culture, either in the form of goods or local arts. Such as, Balinese Gringsing Weaving, Jepara Carved Furniture, Mandar Silk Weaving and so on. Of the many goods products that become commodities in international trade, there are also various commodity products that have very distinctive characteristics, both for products in the form of natural products such as germplasm and products that are processed products. Such products are usually only found or known to come from a certain region and region or in a certain country, so that they are not found and are not known in other regions or countries. Commodity products like this are referred to as products that are exclusive. Exclusive products like this receive a lot of attention and special treatment which in Intellectual Property, (hereinafter referred to as $\mathrm{KI}$ ) is known as Geographical Indication (hereinafter referred to as IG) or Indication of origin. Article 23 of the TRIPs Agreement has specifically agreed to provide protection for all kinds of products, both raw products and processed products through a Geographical Indication protection system or a sign of origin of goods. According to Hendra Djaja, GI is an indication or sign attached to goods originating from a certain place, region or geography that shows certain qualities, reputations or characteristics, including natural or human factors that are used as attributes to the goods produced. The sign used as a geographical indication can be in the form of the name of a place, area, region, word, image or a combination thereof. Protection of products produced in relation to geographical indications includes various types of products obtained from nature, agricultural products, crafts or crafts and so on.[1]

The history of GI recognition was first regulated in the Paris Convention 1883. This convention introduces protective measures on the Border of Measures and protection against unfair competition. Then the regulation of GI was further regulated in the Madrid Agreement 1891 False Indication and Border Of Measures, then also regulated in the Lisbon Agreement in 1958 which regulates international registration of Indications of Origin. the last IG is regulated in the Trade Related Aspects of Intellectual Property Rights (hereinafter referred to as TRIPs) which was signed in the Uruguay Round of the General Agreement On Tarifs and Trade (hereinafter referred to as GATT) in 1994 offering a very broad opportunity for international protection for IG. [2]

Until now, the discussion about GI has become one of the interesting topics in International IP. Born out of a French tradition in the 19th century, and originally reserved for identifying and protecting the geographic origin of wines against imitation, the IG protection was later accepted by other European countries and eventually accepted by the European Union (EU). Then, from Europe, IG became a global phenomenon and became a topic of international controversy in the last two decades. In particular, IG was one of the interesting issues at the negotiating table that led to the formation of the World Trade Organization (WTO) in the late 1980s and early 
1990s. Discussions on IG continue to dominate World Trade Organization Negotiations: The Doha Development Agenda, although WTO Members have never reached agreement on this issue.[3]

According to Christoph Antons, several benefits of protection against Geographical Indications include: [4] "It has been said that GIs can assist with the promotion of rural and regional development; support the emerging creative industries; help to protect traditional cultural expressions; ensure that the exploitation of traditional knowledge would recognize sacred beliefs and practices of traditional peoples; safeguard cultural heritage; promote environmentally sustainable development; and indirectly contribute to an increase in tourism".

This is in accordance with the expression of the World of Intellectual Property Office (WIPO) which says that basically geographical indications have economic importance, therefore protection of GI has benefits, among others:

1. protection of geographical indications will create a market characteristic/identity and if advertised correctly with good intentions it will lead to a high price of a product;

2. protection of geographical indications will pave the way for local producers to develop their brands and to trade under their own market identities; and

3. protection of geographical indications related to property or economic rights (which is the most important meaning).

Regulations regarding GI in Indonesia are regulated in Law Number 20 of 2016 concerning Marks and Geographical Indications, the right to geographical indications is an exclusive right granted by the state to the holder of the registered geographical indication right, as long as the reputation, quality, and characteristics on which it is based are given. protection for the geographical indication is still there. [5] In the geographical indication there are rights that allow to prevent the use by third parties whose products do not comply with applicable standards. Protection of geographical indications is important because geographical indications are also property rights that have economic value, so they need legal protection.

Indonesia has a bitter experience related to claiming the ownership of GI owned by Indonesia. Some of the cases that occurred include: 1 . In the case of Toraja Coffee which is registered in Japan as a trademark "Toarco Toraja" No. Registration 75884722. If you look closely, the dispute in the Toraja Coffee case is a trademark dispute, even though the lawsuit is due to the use of a trademark used by the Japanese as a trademark. However, in fact the product of the trademark recognized by the Japanese is one type of Geographical Indication product belonging to the Toraja community which is currently registered as a protected Indonesian Geographical Indication product. 2. "Gayo Mountain Coffee" trademark claim against Gayo Coffee with CTM Registration. 001242965 by a Dutch company. In this case, the same thing as experienced by Toraja Coffee which is recognized by the Japanese as a trademark. Where in this case the Gayo Aceh coffee which is a Geographical Indication product belonging to the Gayo Aceh community was recognized by the Dutch as a product with the trademark "Gayo Mountain Coffee", until the case was won by the Indonesian side and the Indonesian Government registered it with the World Intellectual Property Organization (WIPO). with the aim of establishing Gayo coffee in the international market.[6]

And the latest is Durian Montong which is claimed by the Thai side which actually belongs to Indonesia because it is produced from the original Indonesian Durian Tree, Dr. Ir. Endang Yuniastuti Msi, Durian Researcher from Sebelas Maret University Surakarta, explained that the "mother" of Montong Durian is Sukun Durian, which was taken from Mataasih, Karanganyar Regency, Central Java. From these native Indonesian species, Thailand then succeeded in developing a superior variety which was later named Durian Montong. Of course, the Indonesian people do not want such an incident to happen again in the future for other Indonesian products. Therefore, in this case the role of the Government is very important in order to protect the existing potentials of Geographical Indications, especially Regional Governments. Local governments must be more serious in socializing, guiding the community as well as conducting an inventory and facilitating the community to register various "typical" (potential) local natural products in their area to be protected as geographical indications, especially if these products have been routinely (traditional) ) has been exported abroad and gained a steady market.

This is because Regional Governments are more aware of the potential of their respective Geographical Indications, in addition to that based on Article 53 Paragraph (3) of Law 20/2016, Local Governments and Community Representative Institutions in the GI area can apply for registration of GIs. Especially in Riau Province where the research was conducted, it is known that out of the 67 registered Geographical Indications, there is not one Geographical Indication originating from Riau Province. If you look closely, actually Riau Province also has several regional superior products spread across various regencies and cities in Riau Province, and even among these products already have a good reputation in the international world. Some of these products include: 1) Bolu Kemojo Siak Sri Indrapura, 2) Shipbuilding techniques in Rokan Hilir, 3) Sago Products from the 
Meranti Islands, and 4) Several handicrafts in the form of weaving or carving.

It is not enough to stop there, it is necessary to elaborate and analyze the law on these issues with the aim of how to obtain maximum legal protection, one of which is by taking an inventory of the potential Geographical Indications owned by Indonesia. Then the results of the potential Inventory of Geographical Indications are registered collectively, this is due to the communal nature of ownership of Geographical Indications. So the technical registration and legal protection should also involve the community as much as possible (both local government and the community). Actually, the regulation regarding the inventory of Indonesia's Geographical Indications potential has been regulated in Article 70 Paragraph (2) letter e of Law 20/2016, but considering the fact that since the enactment of Law 20/2016 dated 25 November 2016 until now, the number of Geographical Indications registered are only about 91 types.

Seeing the fact that the results of the regulation regarding the inventory and mapping of potential Geographical Indications are regulated in Law 20/2016 on the number of Geographical Indications registered with the Director General of Intellectual Property, and it is known that although currently the regulations related to the protection of Geographical Indications are regulated in Law 20/2016 has regulated the inventory and mapping of the potential Geographical Indications owned by Indonesia, but there is no clarity on the next steps after the inventory and mapping is carried out. Based on this, this article aims to dig up information on the factors that hinder the inventory and mapping of potential Geographical Indications..

\section{RESEARCH METHOD}

The type of research used in this research is empirical legal research or non-doctrinal legal research. Legal research is conducted to produce new arguments, theories or concepts as prescriptions in solving problems at hand. Legal research is a scientific activity, which is based on certain methods, systematics and thoughts, which aims to study one or several certain legal phenomena, by analyzing them.[7] This research is included in the type of research that examines the implementation of Article 70 Paragraph (2) letter e of Law 20/2016, namely the norms related to the inventory and mapping of Geographical Indications in the Geographical Indication protection system by either the Central Government or Regional Governments. The research was conducted in Riau Province and at the Directorate General of Intellectual Property (DJKI). In order to facilitate the research process and to see the magnitude of the potential for Geographical Indications in the form of traditional knowledge or the results of natural wealth (both in agricultural and fishery products) from 12 (twelve) regencies/cities in Riau Province.

\section{FINDINGS AND DISCUSSION}

The results of groundstroke learning in playing tennis in each group are explained as follows.

\section{Inhibiting Factors Inventorying and Mapping Potential Geographical Indications in Riau Province}

It is undeniable that Intellectual Property as a right generated by human intellectual ability is very important to obtain adequate legal protection in accordance with the TRIPs Agreement. This needs attention, especially since Indonesia has become a free and open market for products or works both domestically and abroad. Therefore, it is appropriate for these products to require more effective legal protection against all acts and violations that are not in accordance with the provisions as stipulated in the TRIPs/WTO Agreement and international conventions that have been agreed upon. Robert M. Sheerwood, in the journal law and technology, said that economic development is the overall goal of building an effective IP protection system.[8] Property rights attached to the term KI cannot be separated from the economic value of a property as part of material rights. The economic rights are in the form of a monetary benefit obtained due to the use of IP itself, or because of the use by other parties based on a license. The fact that there is economic value shows that IP is one of the objects of trade. [9]

Geographical Indication is a geographical term related to a product that shows the place or area of origin and product quality derived from geographical characters. The GI provisions in the TRIPs Agreement are regulated as an independent Intellectual Property regime, because GI is recognized as having its own characteristics or is sui generis. Even before the regulation and discussion on the protection of Geographical Indication products, brands that use geographic terms have been widely used and registered as trademarks. [10] Protection of Geographical Indications as part of Intellectual Property cannot be separated from the consideration of the inherent economic value of a property. The use of labels or geographical indication marks describes the quality of goods or products produced by a particular region or region. This will indirectly add economic value to a product or goods produced. As revealed by Sophie Reviron: [11] "economic value is the engine of development. Commercial performance related to consumers acknowledgement of the superior quality and typicity is the first objective of GI construction". Further said that ".. however most of GI have the potential to create positive social and environment effects to the benefit of the rural development".

Viewed from the aspect of international trade, the use of geographic names as an indication or indication of the origin of an item has a comparative advantage that is able to increase the competitiveness of the commodity in question. [12] This is felt to be very helpful in increasing the marketing of goods, so that traders encourage their government to provide legal protection for such products, by making international agreements in a multilateral 
manner. The potential of regional goods or products that have unique characteristics to protect geographical indications is a wealth and reality that has added value or economic benefits which is allegedly able to provide increased welfare and benefits for local communities and the local area. [13]

Learning from European countries, geographical indication products can provide great benefits for the country's economy. Wine sales in France rose about $230 \%$ from sales to other countries. Sales of cheese rose between 158-203\%.5 Sales of native Florida oranges from the United States state of Florida, which is widely known worldwide for its distinctive taste, could contribute US $\$ 9$ million, create approximately 80,000 new jobs and expand 230,670 hectares of land. [14] Seeing the magnitude of the economic value, it is important to take an inventory of the potential of Geographical Indications as a preventive effort by the state to prevent claims against the potentials of Geographical Indications by outsiders. -Geographical Indication products belonging to Indonesia which are claimed by outsiders as their own products.

However, what is unfortunate is that of the many potential GIs in Indonesia, only 67 (Sixty Seven) GIs have just been registered with the Ministry of Law and Human Rights. [15] Meanwhile, there are about 13 potential Geographical Indications that are still in the registration process in 2019, this can be seen in the official Geographical Indications news. [16] As a comparison, currently the countries that make maximum use of the Geographical Indication regime as a tool or method to develop regional economies and local communities include Japan, India, and the United States (both in terms of regulation and implementation). For Japan and the United States, almost all products of traditional knowledge and types of plant varieties in those two countries are registered as products of geographical indications. [17] This has an impact on the large profits obtained by the two countries, it is known that geographical indication products can provide great benefits for the country's economy. Wine sales in France rose about $230 \%$ from sales to other countries. Sales of cheese rose between 158-203\%.5 Sales of native Florida oranges from the United States state of Florida, which is widely known worldwide for its distinctive taste, could contribute US\$9 million, create approximately 80,000 new jobs and expand 230,670 hectares of land. [18]

In contrast to Indonesia which has not taken similar steps, amid the large opportunities that can be taken from the economic side by maximizing the utilization of the Geographical Indication regime, only 67 (sixty-seven) have just been registered as Geographical Indication products and 4 (four of them are Geographical Indication products). outside property registered through the international registration mechanism. Meanwhile, for Riau Province the potential for Geographical Indications is from various regencies or cities contained in the province. Based on the author's research in 3 (three) regencies in Riau province, namely: Rokan Hilir Regency
, Kampar, and Siak Sri Indrapura. The potential of Geographical Indications owned by the Province is quite promising, but so far there has been no original Geographical Indication of the area registered. This is certainly contrary to the many potential Geographical Indications in the area. was found after conducting interviews with stakeholder resource persons (Department of Culture) in 3 (three) regencies in the Province, where in general the lack of understanding of stakeholders in the Riau Province environment related to the protection of Geographical Indications and Superior Products of Regional Communities is the cause of not registering to the potentials of the Geographical Indications. Then added that there is no legal politics of the Regional Government with the orientation of providing legal protection and development of the potential Geographical Indications and Regional Superior Products owned, this is known by looking at the absence of Regional Regulations that regulate it. Because it is known that there is a lack of understanding regarding the importance of protecting Geographical Indications and the absence of legal politics of the Regional Government with the orientation of providing legal protection and development of the potential of Geographical Indications and Regional Leading Products owned, as well as the many potentials of Geographical Indications owned by Riau Province, then several efforts that must be made to provide protection against the potential of such Geographical Indications. Some of these steps include:

2. Local governments need to build an understanding of the legal protection of Geographical Indications which includes the benefits, processes, requirements and challenges.

Efforts to build this understanding must be carried out comprehensively among all stakeholders, be it the provincial government, especially the district government, along with all stakeholders, including for agricultural products. Provinces, universities, entrepreneurs, farmer groups and all other interested parties. As for the skills of the community that have been passed down for generations, they are applied in everyday life, such as shipbuilding techniques, woven fabrics, and carvings, the Provincial Government, especially the Regency Government, along with all stakeholders, among others, plays an important role in this matter. are the Department of Culture, the Department of Industry and Trade, the Legal Department of the Regency or Provincial Secretariat, Universities, entrepreneurs, farmer groups and all other interested parties. As for marine products, the Provincial Government, especially the Regency Government, along with all stakeholders, among others, for this matter, those who play an important role are the Department of Marine Affairs and Fisheries, the Department of Industry and Trade, the Legal Department of the Regency or Provincial Secretariat, Universities, entrepreneurs, farmer groups and all other interested parties.

In fact, protection of Geographical Indications has many benefits, not only from an economic point of view, 
but also from an ecological, socio-cultural perspective, as well as legal benefits, as explained by one of the Expert Teams for Geographical Indications from the Directorate General of Intellectual Property of the Ministry of Law and Human Rights, H. Riyaldi who mentions that GI protection has various benefits, both for producers and for consumers. For producers the benefits are as follows: [19] First, the benefits from the economic side include: (a) Preventing the transfer of ownership of the rights to use the uniqueness of the product from the local community to other parties. (b) Maximizing the added value of the product for the local community. (c) Provide protection against product counterfeiting; (d) Increase the marketing of distinctive products; (e) Increase the provision of employment opportunities; (f) Supporting the development of agro-tourism. (g) Ensuring business continuity; (h) Strengthening the regional economy; (i) Accelerating regional development; (j) Improving people's welfare. Second, the benefits from the ecological side, among others; (a) Maintaining and preserving nature; (b) Improve the reputation of the region; (c) Improving the sustainability of germplasm. Third, from a socio-cultural perspective, the benefits of GI are (a) Strengthening relationships between plantations; (b) Improving regional dynamics; (c) Preserving the customs, knowledge and local wisdom of the community. Fourth, the benefits from a legal standpoint are: (a) For producers to provide protection and guarantees of legal certainty; (b) For consumers: provide quality assurance according to consumer expectations of GI products and provide legal guarantees for consumers. Besides, GI protection is recognized and applied internationally.

3. Regency or Provincial Governments need to make policies and be consistent in providing protection for Geographical Indications for products typical of their region.

There is no Regional Legal Product which is functioned to make an inventory and/or to provide protection against potential Geographical Indications owned or Regional Superior Products. This certainly shows that the region does not have the seriousness to protect its superior potential, this is in accordance with the opinion of Asma Karim and Dayanto that:[20] "The form of seriousness in the protection of potential GI products carried out by local governments is in the form of making a legal framework regarding the legal protection of products or goods". In this case, the formation of the Regional Legal Product must be used to speed up the product registration process from the potential Geographical Indications of the area, by: a. District or provincial governments need to prepare groups of officers and experts and b. The Regency or Provincial Government needs to increase the knowledge of farmers, or potential producers of Geographical Indications as well as the growth and strengthening of groups that produce potential Geographical Indications by working groups and related work units.

This needs to be done immediately considering that Indonesia is currently approaching the ASEAN Economic
Community, which makes Indonesia have an opportunity as a potential world market, an investment destination country, and an opportunity as an exporting country. [21] Therefore, the protection of Geographical Indications in addition to functioning to protect against actions in the form of producing products that seem to come from their place of origin, which is one of the modes of fraudulent acts which are categorized as unfair competition. Actions by other producers outside the country of origin, are considered as trade practices that are contrary to Fair trade principles, also for marketing purposes, the protection of GI can be used as a means of promotion and "passport" for the export of goods. Geographical Indications have been proven to be able to promote products by developing a market profile for goods that have a good reputation. [22]

Departing from this, the author concludes that the protection of the potential for Geographical Indications in the form of mapping and inventory in Indonesia and especially Riau Province is still not maximized, because the relevant stakeholders who play a role and the public in general do not know the importance of registration and understand the concept of IP, especially GI. This is a result of the absence of socialization or legal counseling provided by the Government (both Central and Regional). Therefore, in addition to the need for the role of the region to speed up the process of protection (registration) using Regional Legal Products, it is also necessary to regulate on a national scale to speed up the registration process. Based on this, the authors argue that a useful policy is needed to optimize the protection of potential Geographical Indications before being registered as Geographical Indications. This can be done by optimizing the inventory of potential Geographical Indications that exist in various regions in Indonesia, before being registered as a product of Geographical Indications collectively.

\section{CONCLUSION}

Based on the results of the study, it is known that the lack of understanding of the community and stakeholders in the region (especially Riau Province) about the concept of protecting Geographical Indications causes many potentials for Geographical Indications in the Region which are actually Regional Superior Products not to be registered. The geography and benefits of its protection by the Directorate General of Intellectual Property, coupled with ambiguous regulations (ambiguity law) and indecisiveness in the editorial contained in the explanation of Article 70 Paragraph (1) of Law 20/2016 causes unclear arrangements regarding the institutions authorized to carry out mapping and inventory of potential Geographical Indications that exist in Indonesia, as well as unclear norms governing the inventory and mapping of potential Geographical Indications whether carried out after the application for registration or indeed required jiban from the Directorate General of Intellectual Property to carry out the mandate even though there has been no application for registration of Geographical Indications.. 


\section{REFERENCES}

[1] Hendra Djaja, "Perlindungan Indikasi Geografis Pada Produk Lokal Dalam Sistem Perdagangan Internasional", Jurnal Cakrawala Hukum, Vol.18, No.2 Desember 2013,

[2] Ach.Tahir, Iswantoro, Siti Fatimah, Resti Dian Luthviati, Rian Saputra, Abdul Kadir Jaelani. The Model Of Criminal Policy To Customary Law Society After Decision Of The Constitutional Court Of The Republic Of Indonesia Number 95/PUU-XII/2014. International Journal of Advanced Science and Technology Vol. 29, No. 4, (2020)

[3] Agreement On Trade-Related Aspects Of Intellectual Property Rights, April 15, 1994, Marrakesh Agreement Establishing The World Trade Organization, Annex 1c, 1869 U.N.T.S 299 [Hereinafter Trips]; World Trade Organization, Ministerial Declaration Of November 14, 2001, Wto Doc. Wt/Min(01)/Dec/1, 41 I.L.M. 746 (2002) [Hereinafter Doha Declaration]. Lihat Juga Dalam Irene Calboli, "Geographical Indications Between Trade, Development, Culture, And Marketing: Framing A Fair(Er) System Of Protection In The Global Economy?", In The Geographical Indications Atthe Crossroads Of Trade, Development, And Culture Focus On Asia-Pacific, (Irene Calboli \& Ng-Loy Wee Lon Eds., 2017), Cambridge University Press.

[4] Graham Dutfield, "Geographical Indications And Agricultural Community Development: Is The European Model Appropriate For Developing Countries?", In The Intellectual Property And Food Project:From Rewarding Innovation And Creation To Feeding The World 175, 176 (Charles Lawson And Jay Sanderson Eds., 2013); Sarah Bowen, Development From Within? The Potential For Geographical Indications In The Global South, 13 J. World Intell.Prop. 231, 233- 35 (2010).

[5] Djulaeka, Konsep Perlindungan Hak Kekayaan Intelektual: Prespektif Kajian Filosofis Haki Kolektif-Komunal, Malang: Setara Press, 2014.

[6] Rian Saputra, Adi Sulistiyono \& Emmy Latifah, Pendaftaran Internasional Sebagai Upaya Perlindungan Indikasi Geografis Indonesia Dalam Perdagangan Global (Studi Peraturan Pemerintah Nomor 22 Tahun 2018), Jurnal IuS Kajian Hukum dan Keadilan, Vol 7 Nomor 2 Agustus 2019.

[7] Soerjono Soekanto, Pengantar Penelitian Hukum, Jakarta: UI Press, 2008

[8] Robert M. Sheerwood, "The Trips Aggreement: Implication For Developing Countries", The Jurnal Law And Technology, Vol. 37, 1997

[9] Tatty Aryani Ramli, et.,all "Urgensi Pendaftaran Indikasi Geografis Ubi Cilembu Untuk Meningkatkan Ipm”, Jurnal Sosial Dan Pembangunan Mimbar, Vol. 26, No. 1 Tahun 2010,

[10]Dwijen Rangnekar, 2003, Geographical Indications, A Review of Proposals at the TRIPs Council: Extending Article 23 to Products other than Wines and Spirits, Geneva, ICTSD dan UNCTAD.

[11]Shopie Revron, Geographical Indication Creation And Distribution of Economic Value In Developing Countries, Sebagaimana Dikutip Dalam Buku Djualeka, Konsep Perlindungan Hak Kekayaan Intelektual: Prespektif Kajian Filosofis Hki Kolektif-Komunal, Malang: Setara Press, 2014,

[12] Wahyu Sasongko, 2010, Indikasi Geografis: Studi tentang Kesiapan Indonesia Memberikan Perlindungan Hukum terhadap Produk Nasional, Disertasi, Universitas Indonesia, Jakarta.

[13] Rian Saputra, Development of Creative Industries as Regional Leaders in National Tourism Efforts Based on Geographical Indications. Jurnal Bestuur Vol. 8, Issue 2, December, 2020

[14] Indra Rahmatullah, Perlindungan Indikasi Geografis Dalam Hak Kekayaan Intelektual (Hki) Melalui Ratifikasi Perjanjian Lisabon, Jurnal Cita Hukum, Vol. I No. 2 Desember 2014,

[15]H. Riyaldi, Perlindungan Indikasi Geografis Manfaat Dan Tantangannya, Departemen Hukum Dan Ham Ri, Direktorat Jenderal Hak Kekayaan Intelektual", Jakarta, Media Hki, Vol.V/N0.04/Agustus, (2008)

[16] Asma Karim Dan Dayanto, Perlindungan Hukum Dan Pengembangan Potensi Indikasi Geografis Minyak Kayu Putih Pulau Buru, Jurnal Rechtsvinding, Vol. 5 No. 3, Desember 2016.
[17] Mansur Tiurmaida Malau, Aspek Hukum Peraturan Dan Kebijakan Pemerintah Indonesia Menghadapi Liberalisasi Ekonomi Regional : Masyarakat Ekonomi Asean 2015, Jurnal Rechtvinding Vol. 3 No. 2 Agustus 2014

[18] Kartadjoemena, 1977, Gatt-Wto Dan Hasil Uruguay, Penerbit Universitas Indonesia, Jakarta.

[19]Rian Saputra, 2020. Inventarisasi Potensi Indikasi Geografis Dalam Upaya Memperkuat Sistem Perlindungan Hukum Terhadap Indikasi Geografis di Indonesia (Studi di Provinsi Riau), Tesis, Magister Hukum Universitas Sebelas Maret.

[20]Rian Saputra \& Resti Dian Luthviati Institutionalization of the Approval Principle of Majority Creditors for Bankruptcy Decisions in Bankruptcy Act Reform Efforts. Journal of Morality and Legal Culture, Vol. 1, No. 2, December 2020.

[21]Rian Saputra, Pergeseran Prinsip Hakim Pasif Ke Aktif Pada Praktek Peradilan Perdata Perspektif Hukum Progresif. Wacana Hukum . Vol 2 No 1, Juni 2019.

[22] Siti Fatimah, Udiyo Basuki Iswantoro, Rian Saputra, Abdul Kadir Jaelani. The Public Policy Of Local Government In Protecting Geographic Indication As A Leading Regional Product. International Journal of Advanced Science and Technology, Vol 29. Issue 4, Tahun 2020. 